\title{
AZ IDEÁLIS PARTNER: EGY GRÚZIAI KÉPZÉS HAZAI TAPASZTALATAI BOGdán PÉter
}

a Magyar Tudományos Akadémia Társadalomtudományi Kutatóközpont Kisebbségkutató Intézetének tudományos segédmunkatársa bogdan.peter@tk.mta.hu

2014. augusztus 1. és 2015. március 1. között valósult meg a Me\&You-projekt ${ }^{1}$ nyolc - európai és Európán kívüli - ország részvételével. A nemzetközi tréningsorozatot, amely része az Europe Strategy 2020 megnevezést viselő EU-s növekedési stratégiának, az Európai Bizottság Erasmus + az Európai Unió oktatási, képzési, ifjúsági és sportprogramja támogatta, a lettországi Nemzetközi Ifjúsági Programok Ügynöksége koordinálta. A projekt megálmodói a szintén lettországi NVO ideA (nem kormányzati szervezet) munkatársai és partnerei voltak.

A Me\&You-projekt az informális oktatásban használt „lány és fiúcsoportmódszeren" alapul, amelyet a finn Åland Islands Peace Institute fejlesztett ki abból a célból, hogy támogassa a tinédzsereket az identitásfejlődésben, a személyes értékek formálásában, valamint a belső tartalékok felfedezésében. ${ }^{2}$ A „, lány és fiú-csoportmódszer" tulajdonképpen egy „,megerösitö módszer”, amelynek során kitüntetett figyelmet szentelnek a nemek, valamint a nemi szerepekhez kötődő hatalmi struktúrák közötti igazságtalanságok beazonosításának, de emellett a tinédzserek fontos témákat (kapcsolatok, család, szex, oktatás, társadalmi kirekesztés) is megvitatnak, illetve megvizsgálnak.

A , lány és fiú-csoportmódszert” az Åland Islands Peace Institute-tal (a Central Baltic Interreg IV A Programme 2007-2013 keretében) együttmüködő Resource Center For Women „Marta” (nem kormányzati szervezet) vitte el székhelyére, Lettországba, ahol a Me\&You-projekt ötlete azután született meg, hogy Madara Mazjāne három évig alkalmazta ezt a metódust több mint 150 fiatallal. A Resource Center For Women „Marta” szervezet tapasztalata szerint a csoportmódszer változásokat indukált a fiatalok attitüdjében és viselkedésében, megnövekedett az önbizalmuk, bekapcsolódtak társasági tevékenységekbe, biztonságérzetük fejlődött, megnövekedett a figyelmük a nemi szerepek és az egyenlőség iránt, ami egyben elősegítette a fiatalok inklúzióját is a társadalomba. ${ }^{3}$

1 A projektről lásd részletesebben: http://www.projectmeandyou.com/\#!home/mainPage Letöltés ideje: 2016. március 27.

${ }^{2}$ http://www.projectmeandyou.com/\#!project-method/cee5 Letöltés ideje: 2016. március 27.

${ }^{3}$ http://www.projectmeandyou.com/\#!who-are-we/c1il6_Letöltés ideje: 2016. március 27. 
A „lány és fiú-csoportmódszerre” építő Me\&You-projekt általános céljai a következőképpen fogalmazhatóak meg4:

1. a Europe Strategy 2020 stratégia aktív részese lenni az által, hogy a program támogatja a nemek egyenlőségén alapuló társadalmi inklúziót;

2. beazonosítani és összehasonlítani a nemi vonatkozású és aktuális problémákat Európában és a szomszédos államokban, valamint megérteni azok okait és következményeit;

3. az ifjúságsegítők és oktatási szakemberek készségeit gyarapítani olyan módszerek hozzáférhetővé tételével, amelyek a nemi egyenlőséget helyezik a középpontba;

4. erősíteni a nemzetközi együttmüködést olyan szervezetek között, amelyek a nemekkel és a nemi szerepekkel kapcsolatos problémákra specializálódnak.

Ami a konkretizált célkitüzéseket illeti, azok pedig a következők:

1. megismertetni a projekt résztvevöit és küldö szervezeteiket a Europe Strategy 2020 elképzeléseivel, valamint elősegíteni a partnerszervezetek abba történő bevonódását;

2. helyi közösségekben való tevékenységek megvalósításán keresztül a partnerszervezetek végezzenek nemi szerepekkel, egyenlőséggel és társadalmi kirekesztéssel kapcsolatos kutatásokat;

3. grúziai nemzetközi tréningen a résztvevők végezzenek összehasonlítást és kritikai analízist a nemi kérdésekkel kapcsolatban globális perspektívából;

4. együttmüködés kialakítása az Európai Unió és a szomszédos országok szervezetei között;

5. a résztvevők megismertetése a ,lány és fiú-csoportmódszerrel”, annak céljaival és eszközeivel a módszer megtanulásán keresztül;

6. a grúziai képzés után helyi tevékenységek szervezése, amelyek keretében minden partnerszervezet alkalmazza a tanult , lány és fiú-csoportmódszert" a saját közösségében (tinédzserek csoportja, fiatal felnőttek, ifjúságsegítők);

7. a ,lány és fiú-csoportmódszer" fenntarthatóságának és hatékonyságának értékelése, a problémák és eredmények összesítése, a partnerszervezetek közötti jövőbeli együttmüködés megtervezése, valamint egy tapasztalatcsere-szeminárium szervezése Magyarországon.

A Me\&You-projektben 8 ország olyan nem kormányzati szervezetei vettek részt, amelyek föprofilja a fiatalokkal (tinédzserekkel) való foglalkozás. A következő szervezetek képviseltették magukat (összesen 24 oktatási szakemberrel): NVO ideA (Lettország), Youth Association Droni (Grúzia), Young Ukrainian Leaders

\footnotetext{
${ }^{4}$ http://www.projectmeandyou.com/\#!about-us/cjg9 Letöltés ideje: 2016. március 27.
} 
(Ukrajna), Deneyimsel Egitim Merkezi Dernegi (Törökország), MRSZ Alapitvány Önkéntes Diakóniai Év Programiroda (Magyarország), SKUNK Skärgårdsungdomarnas Interesseorganisation (Åland Islands), Yuva Humanitar Merkezi (Azerbajdzsán), Centru Pentru Dezvoltare Durabila Greentin (Románia). A kobuleti-i képzés vezérfonalát a trénereknek (Madara Mazjāne, Lauma Ziemelniece, Levendel Áron) a következő hitvallása képezte: „A nők és férfiak kölcsönös kapcsolatára épülő nemi szerepek és sztereotípiák évszázadok óta fontos és sokat vitatott témák. Hiszünk benne, hogy mindannyian felelösek vagyunk azokért az értékekért, amelyeket átadunk a következő generációknak. Ez jelenti azt, hogy kritikával kell viszonyulni a saját érték- és hitrendszerünkhöz, mint ahogyan kritikusan kell kielemezni azt is, hogy mit akarunk beleinvesztálni a következő generációkba." 5

Ezen gondolatok jegyében 9 olyan fontosabb - coaching technikákat alkalmazó - módszerrel ${ }^{6}$ ismerkedhettek meg a résztvevő szakemberek, amelyektől az várható, hogy a tréningen képviselt szervezetek fiataljai tudatosabban és érzékenyebben lesznek képesek kezelni a férfi-női kapcsolatrendszerek komplex aspektusait. Azaz a Me\&You-projektnek szerves részét képezte a 9 módszer továbbvitele a résztvevő 8 országba helyi mini-tréningek formájában. Magyarországon erre - Dénesné Szanyi Ildikó irányításával - Budapesten került sor, de volt gilvánfai helyszín is Sarah Braun vezetésével, valamint bekapcsolódott ezenfelül a Budaörsi Tanoda a személyes közremüködésemmel.

Magyarországon 2014. november 30-án tartottuk a helyi workshopot a Budaörsi Tanodában. Az eredeti céloknak megfelelően középiskolás tanulókat és az intézmény pedagógusait céloztuk meg, de az előzetes szervezéshez képest (több jelentkező diák volt, mint aki végül megjelent) nem sikerült nagy volumenű képzést tartani, ugyanakkor a jelenlévő három tanuló (két fiú és egy lány) és két pedagógus tevékenysége alapján hasonló tendenciák és reakciók voltak lemérhetők és tapasztalhatók, mint a grúziai Kobuletiben tartott (képzők képzése) tréningen.

A mini-workshopot jégtörő játékkal kezdtük, amely nagyon gyorsan oldott és pozitív légkört teremtett a résztvevők között, aztán rátértünk a Me\&You-projekt által felkínált módszerekre. Az első játék a Hot Chair volt. Ennek a foglalkozásnak a keretében kört alakítottunk ki székekböl, mindenki leült az általa legszimpatikusabbnak talált helyre, s elhelyeztünk magunk között egy üresen álló széket is, mégpedig azért, mert a módszer keretében a tanulók és a tanárok olyan kérdéseket hallhattak, amelyekkel kapcsolatban állást kellett foglalniuk. Ennek megfelelően ha egyetértettek a megfogalmazottakkal, akkor helyet kellett cserélniük,

${ }^{5}$ http://www.projectmeandyou.com/\#!home/mainPage Letöltés ideje: 2016. március 27. Fordítás Bogdán Péter.

${ }^{6}$ Activity „Mary and John; Activity „4 corners” (Sexual Identity); Activity „7 methods of suppression”; „Activity „An Alien”; Activity „Female/Male Sexual Identity , Activity „Grey Zone Stories”, Activity „Hot Chair”, Activity „Ideal Partner”; Activity „Identity Molecule” 
ha pedig nem, vagy bizonytalankodtak, akkor ott maradtak, ahová eredetileg is leültek. Minden egyes döntés után a moderátor feltette a kérdést - személyre szólóan - hogy ki és miért változtatott vagy nem változtatott helyet.

A játék során voltak bemelegitő állitások (1. A kedvenc színem a kék. 2. szeretem az extrém sportokat 3. Szeretek bevásárolni. 4. Nem szeretnék vidéken élni. 5. Félek a pókoktól és a kígyóktól. 6. Szeretek könyveket olvasni. 7. Nem szeretek mosogatni.); nemi szerepekkel kapcsolatos állitások (1. Elfogadható, ha egy nő magasabb a partnerénél. 2. Egy férfinak vigyáznia kell a partnerére. 3. Egy nőnek rossz híre keletkezhet, ha provokatívan öltözik fel. 4. Elfogadható, ha egy férfi kevesebbet keres a feleségénél 5. Egy nő rendszeresen meghívhatja a partnerét vacsorára és fizetheti is azokat.); szexualitással, szexuális identitással kapcsolatos állitások (1. A férfiak jobban szeretik a szexet, mint a nők. 2. Egy nőnek a házasságig szüznek kellene maradnia. 3. Nem okozna nekem problémát, ha kiderülne, hogy a legjobb barátom homoszexuális 4. A szex célja a szerelem kifejezése. 5. Az óvszerről való tudás arra indíthatja a fiatalokat, hogy szexuális viszonyt létesítsenek) férfiassággal/nőiességgel kapcsolatos állitások (1. A férfinak kellene felelősnek lennie a családi életben minden fontos döntésért. 2. A futball egy tipikus férfi sport. 3.Elfogadhatatlan, ha egy nő tesz házassági ajánlatot egy férfinak. 4. A gyermekek gondozása a nő kötelessége. 5. A férfiak sokkal racionálisabban és logikusabban gondolkodnak, mint a nők. 6 . Az a férfi, amelyik kimutatja az érzéseit: gyenge. 7. A nők többet beszélnek, mint a férfiak. 8. Minden férfi egyforma. 9. Mostanában a fiatal lányok túl sok kozmetikumot használnak. 10. Azok a férfiak, akiknek volt néhány szexuális kapcsolata: jó fiúk, de ha lányok teszik ugyanezt: azok könnyen kaphatók. 11. A férfiak sokkal inkább vannak privilegizált helyzetben, mint a nők. 12. A nőknek és a férfiaknak egyenlőknek kellene lenniük).

Az állítások erősen vibráló vitákat generáltak a diákok között. A nők és a férfiak hagyományos nemi szerepeihez nagyon nyitottan közelítettek, ugyanakkor érdekes tapasztalat volt az, hogy míg a fiú tanulók konzervatív álláspontot foglaltak el a homoszexualitással kapcsolatban, addig a lány diák határozottan biszexuális szemszögböl értelmezte a felvetett témákat.

A budaörsi mini-workshop következő állomása az Alien címü játék volt. Ennek a módszernek a keretében a résztvevőknek azt kellett elképzelniük, hogy a Földre érkezett egy földönkívüli humanoid, aki kapcsolatokra vágyik, de nem tudja, hogy hogyan kell viszonyulni a különféle embertípusokhoz, mikor tekinthető vonzónak az ellenkező nem számára, de nem tud semmit a földi emberek szexuális szokásairól sem, mint ahogyan ismeretlenek előtte az egyéb -vonatkozó - hagyományok is. A játék szerint a humanoid lehetett nő- és férfi nemü is, s ennek megfelelően a játékosok dönthettek arról, hogy milyen nemü földönkívülinek adnak tanácsot, de az közös volt minden esetben, hogy a gondolataikat címszavakban és rajzos formában egy papírlapon rögzítették. Az eredmények azt mutatták, hogy a résztvevők az általános társadalmi normák mentén gondolkodnak a különböző nemi szerepekről. Azaz ha a földönkívüli humanoid nőnemü volt, akkor úgy vélték, hogy kedvesnek, 
szépnek, viccesnek és sportosnak kell lennie, de ha férfi nemü, akkor a kedvesség mellett megjelent a gazdagság fogalma is, és azt is hozzátették, hogy jó focistának kell lennie, ugyanakkor nem szabad büszkélkednie a vagyonával. A biszexuális leány tanuló egyéni állásfoglalást fogalmazott meg, amennyiben úgy vélte, hogy az általa ábrázolt hímnemü humanodinak biszexuálisnak kell lennie, és érzékenynek kell lennie a különböző emberi kapcsolatokra, mert bármelyiknek lehetnek szexuális következményei.

A mini-workshop egyik legizgalmasabb része Mary és John története volt. A leírás szerint egy szerelmes párról van szó az esetükben, akik szétszakadnak John (16 éves) Európába költözése miatt. A fiatalok internetes eszközökön keresztül sürün tartják egymással a kapcsolatot, de Mary-nek (15 éves) ez nem elég, mindenképpen látni szeretné Johnt. A szüleinek nincs pénze arra, hogy kifizessék neki az útiköltséget, ezért kisebb munkákat vállal el, de még így is kevés az, ami összegyülik. Mary egy diszkóban találkozik Kris-szel (18 éves), aki elmondja, hogy Európába utazik és őt is magával viszi Johnhoz, de előtte le kell vele feküdnie. Mary az édesanyjától kér tanácsot, de ő azt válaszolja, hogy ez az ő élete és elég nagy már ahhoz, hogy önállóan döntsön. Mary eltölt egy éjszakát Kris-szel és elutazik Johnhoz, aki nagyon megörül neki, de csak addig, amíg meg nem tudja, hogy milyen áron utazott el hozzá. A fiú kiadja Marynek az útját. A lány pedig otthon elpanaszolja a bánatát Leonnak (15 éves), aki azt mondja, hogy ne aggódjon, mert ő tudja, hogy mi a megoldás. A játékosoknak egyrészt értékelniük kellett 1-től 5-ig, hogy kinek a viselkedése a legelfogadhatatlanabb (1) és a legelfogadhatóbb (5). Másrészt válaszolniuk kellett azokra a kérdésekre, hogy: Mi lett volna Mary-töl a legelfogadhatóbb viselkedés?, Az anyának mit kellett volna másként tennie?, Ki tudott volna tanácsot adni Marynek?. Hogyan tud Leon segiteni Maryn?. Hogyan változna a szituáció, ha Mary és John szerepet cserélnének? A résztvevök közül mindenki azt mondta, hogy Kris viselkedése volt a legkevésbé elfogadható, amellyel szemben Leoné volt a legelfogadhatóbb. Általában úgy vélekedtek, hogy Kris után Mary anyja a legnegatívabb szereplő a történetben, míg ezzel ellentétben - és Leon után - Mary viselkedése volt a legelfogadhatóbb. Johnnak a megítélése - az értékelési skálán - középen helyezkedett el. Érdekes tapasztalat volt, hogy a grúziai egyetemistákhoz hasonlóan a budaörsi játékosok sem tudták eldönteni, hogy miként értékeljék Leon segítőkészségét, mert ugyanúgy ők sem tudták elképzelni, hogy miben tudna segíteni, különösen annak fényében, hogy Kris is ígért már Mary-nek hasonlót.

Mary és John története után a résztvevők azt a feladatot kapták, hogy készítsenek reklámot a homoszexualitásról egy fiú- és egy leánycsoport keretében. A fiúk - konzervatív heteroszexuális szempontból készítették el - szituációs gyakorlatukat, amelynek az volt az üzenete, hogy a homoszexualitás csak akkor elfogadható, ha annak nincsenek látható jelei. A női csapat ezzel szemben progresszív szellemiségủ reklámot készített. Különböző családtípusokat mutattak be, miközben beszéltek a genetikai adottságokról is. Az ő érvük az volt, hogy senki 
sem tudhatja, hogy ki a heteroszexuális, a biszexuális vagy homoszexuális, és senki sem tudhatja, hogy a heteroszexuális vagy a homoszexuális család müködik-e jobban.

A reklámkészítés után a 4 corners címü játék került sorra. Ennek keretében a moderátor állításokat fogalmazott meg, amelyekre - a terem 3 sarkában elhelyezett - 3 különböző választ is lehetett adni. A játékosok minden állításnál aszerint álltak be egy-egy sarokba, hogy mikor, melyik választ tartották magukra nézvést érvényesnek. Ha egyik opció sem felelt meg akkor az üresen maradt 4. sarkot is lehetett választani. Minden egyes kör után meg kellett indokolni a választást. A 4 corners során a következő kérdésekre és szituációkra kellett választ adni: Mely értékek a legfontosabbak neked egy kapcsolatban? (vonzó külső, támogatás és megértés, együttes szórakozás), Mi a legrosszabb, ami egy barátságban történhet? (hazugságok és rágalmazás, kritika, közömbösség), A nők legalább annyira akarják a szexet, mint a férfiak. (azonos módon akarják, de másképp mutatják ki; nem, a nők akarják inkább; nem, a férfiak akarják inkább), a férfinak joga van a szexhez? (igen, ha a nő flörtölt vele; nem, kivéve akkor, ha a nő is akarja; igen, ha egy párt alkotnak és korábban már szexeltek), Egy partin egy lány flörtöl és táncol néhány fiúval. A parti után kettejükkel hazamegy. Amikor a lány házába érnek, akkor ö behivja öket egy csésze teára. A házban a fiúk leveszik a lány ruháját arra való hivatkozással, hogy a lány felcsigázta őket. Megeröszakolják a lányt. Ki hibázott? (a felelösség a fiúké; a lány csak magát okolhatja; a fiúknak felelniük kell a tettükért, de a lány is felelös - Mi változik, ha a fiúk 18 éven felüliek, de a lány nem? Mi változik, ha mindannyian 18 év alattiak? Mi változik, ha egy fiú és két lány van (azaz megváltoznak a szerepek)?, Rendezvényt szerveznek a nemi egyenlöségröl az iskolában. Néhány lány elérte, hogy minden lánynak kötelezö részt venni a „női önvédelem (mind pszichikai, mind fizikai)" címü tanfolyamon. Mit gondolsz róla? (nagyon jó és szükség van rá; egyáltalán nem szükséges; mindenkinek részt kellene vennie ilyen típusú tanfolyamon), Ki a felelös a tinédzserek szexuális neveléssel, valamint a reprodukciós egészséggel kapcsolatos kérdéseinek megválaszolásáért? Hol kell ennek megtörténni? (a családban; az iskolában; sehol, a tinédzserek már sokat tudnak és meg fogják találni az információkat maguktól). A 4 corners címú játék során nem egyszer élénk vita alakult ki a résztvevők között, habár az is igaz, hogy számos ponton véleményazonosság is tapasztalható volt.

A mini-workshop során az Ideal partner volt a legnépszerübb játék, ugyanis a résztvevők kérésére kétszer is meg kellett ismételni. A módszer az egyéni értékek és identitások kérdésköreit célozza, miközben az individuális, lokális és globális szinten megvalósuló sztereotípiák mögé is be akar hatolni. A játék során a résztvevők először különböző nemzetiségű személyneveket kaptak, aztán a szimpatikus nevek kiválasztása után az adott személy külső megjelenésére vonatkozó információkat. A résztvevők ezután eldönthették, hogy továbbra is kitartanak-e választottjuk mellett, vagy más személyt találnak szimpatikusabbnak. Miután állást foglaltak a játékosok másodjára is, lépésről lépésre szembesülhettek a kiszemelt partner belső 
tulajdonságaival, aztán vallásával, életstílusával, azzal, hogy mit birtokol, mit tud, mit csinál, milyen képzettséggel rendelkezik, hány éves, hol dolgozik, milyen jövőbeli tervei vannak, milyen mondás (hitvallás) származik tőle. Természetesen minden egyes stáció után a moderátor teret adott a játékosoknak arra, hogy elgondolkodjanak azon, vajon továbbra is ki akarnak-e tartani az eredeti partnerük mellett, vagy van olyan, aki időközben szimpatikusabbá vált nekik? A játék legérdekesebb tapasztalata az volt, hogy a fiúk megpróbáltak kitartani mindenáron az első választottjuk mellett, miközben a lányok rugalmasabbak voltak a váltás tekintetében. Az is érdekes tapasztalat volt, hogy a kiszemelt partner hite (vallási nézete) minden esetben hatalmas problémákat okozott. Az volt az a pont, amikor a résztvevők azt mondták, hogy inkább másik személyt választanak.

A mini-workshop zárásaként előkerült az Open Space nevü játék, amelynek keretében a résztvevők kérdéseket tehettek fel a játszott programelemekkel kapcsolatosan, s megfogalmazhatták, hogy mit tanultak és mit vinnének haza. Ez utóbbival kapcsolatosan azt mondták: 1. Minden tetszett. Mindent hazavinnék. 2. A Hot Chair, az Ideal Partner és a 4 corners fanatsztikus volt. 3. A Hot Chair, a homoszexualitás reklámozása, az Ideal Partner volt jó. Örültem, hogy nyiltan beszélhettem a homoszexualitásról. Nagyon jól éreztem magam.

A 2014. október és 2014. december között megvalósított program során 21 résztvevő 24 különböző mini-workshopot rendezett 8 országban körülbelül 500 (14 és 60 év közötti) embernek. A résztvevők 89 órát töltöttek együtt, a miniworkshopok 11 iskolában, 6 egyetemen, 4 oktatási központban és 2 nemkormányzati szervezetben valósultak meg 9 nyelven, 19 különböző nemzetiséget képviselve. A projekt résztvevőinek $52 \%$-a volt férfi és $48 \%$-a volt nő.

A programnak volt folytatása North\&South-Me\&You címmel (területi és résztvevő országok szempontjából) észak és dél relációjában 2015. augusztus 1 . és 2016. április 1. között, valamint Open Senses címmel 2015. augusztus 17. és 2016. január 17. között, de ez utóbbi esetben a „lány és fiú-csoportmódszer” felnőttekre adaptált változatára a ,nők és férfiak- csoportmódszerre” építettek a képzők. 